\title{
PEMANFAATAN ZEOLIT ALAM TERAKTIVASI SEBAGAI ADSORBEN UNTUK MENURUNKAN BOD DAN COD PADA LIMBAH CAIR INDUSTRI TAHU
}

\author{
Ni Wayan Trisnadewi, Ketut Gede Dharma Putra* dan I Nengah Simpen \\ Program Studi Kimia FMIPA Universitas Udayana, Bukit Jimbaran, Badung, Bali 80361 \\ *Email: gededharmaputra@unud.ac.id
}

\begin{abstract}
ABSTRAK
Limbah cair yang dihasilkan oleh industri tahu masih mengandung padatan tersuspensi dan zat terlarut yang dapat mencemari perairan. Salah satu cara yang dapat dilakukan adalah dengan cara adsorpsi. Dalam penelitian ini zeolit alam teraktivasi digunakan sebagai adsorben untuk menurunkan BOD (Biochemical Oxigen Demand) dan COD (Chemical Oxigen Demand) dalam limbah cair industri tahu. Penelitian ini bertujuan untuk mengetahui massa optimum, suhu optimum zeolit dalam limbah dan persentase maksimum pada penurunan BOD dan COD limbah cair industri tahu. Sebelum digunakan, zeolit alam diaktifkan menggunakan $\mathrm{HCl} 6 \mathrm{~N}$ dan $\mathrm{NH}_{4} \mathrm{NO}_{3} \mathrm{~N}$, hasilnya kemudian dikalsinasi pada suhu $300{ }^{\circ} \mathrm{C}$. Hasil penelitian menunjukkan bahwa penurunan BOD pada beberapa variasi massa, 0,$5 ; 1,0 ; 1,5 ;$ dan $2,0 \mathrm{~g}$ berturut-turut 64,$28 ; 71,42 ; 85,7 ;$ dan $78,5 \%$, sementara penurunan COD adalah 18,$5 ; 23,8$; 35,7 ; dan $32,7 \%$. Penurunan BOD pada variasi suhu 50,40 dan $30^{\circ} \mathrm{C}$. berturut-turut adalah 35,$7 ; 42,8$; dan $85,7 \%$ sementara penurunan COD berturut-turut adalah 7,9; 12,5; dan 35,7\%. Penurunan BOD dan COD limbah yang diinteraksikan dengan zeolit tanpa aktivasi pada massa $1,5 \mathrm{~g}$ dan suhu $30{ }^{\circ} \mathrm{C}$ masing-masing sebesar $57,1 \%$ dan $3,3 \%$.
\end{abstract}

Kata kunci : adsorpsi, BOD, COD, limbah cair tahu, zeolit alam

\begin{abstract}
Wastewater produced by tofu industrial still contains suspended solids and dissolved substances that can pollute the water. One method that can be used to reduce the pollutant is adsorption method. This research investigated the use of natural zeolite as an activated adsorbent to lower the BOD (Biochemical Oxigen Demand) and COD (Chemical Oxigen Demand) in wastewater of tofu industry. The aim of the study was to determine the optimum massa, the optimum temperature of the zeolite in the effluent and the maximum percentage of the reduction of BOD and COD in the wastewater of tofu industry. Before use, the adsorbent was activated using $6 \mathrm{~N} \mathrm{HCl}$ and $\mathrm{NH}_{4} \mathrm{NO}_{3} 2 \mathrm{~N}$, the result was then calcinated at a temperature of $300{ }^{\circ} \mathrm{C}$. The results showed that the reductions in BOD of each massa variations, namely $0.5 ; 1.0 ; 1.5$; and $2,0 \mathrm{~g}$ were of $64.28 ; 71.42 ; 85.71$; and $78.57 \%$, respectively, while the reduction in COD were of $18.54 ; 23.84 ; 35.76$; and $32.45 \%$, respectively. The BOD decreases at the temperature of 50,40 and $30^{\circ} \mathrm{C}$ were of $35.71 ; 42.85$; and $85.71 \%$, respectively while the COD reductions were $7.94 ; 12.58$; and $35.76 \%$. The $\mathrm{BOD}$ and $\mathrm{COD}$ in wastewater decreases in intractions with zeolite without activation on a mass of $1.5 \mathrm{~g}$ and a temperature of $30^{\circ} \mathrm{C}$ were $57.14 \%$ and $3.31 \%$, respectively.
\end{abstract}

Keywords : adsorpsion, BOD, COD, natural zeolite, tofu wastewater

\section{PENDAHULUAN}

Tahu merupakan salah satu jenis makanan sumber protein dengan bahan dasar kacang kedelai yang sangat digemari oleh masyarakat Indonesia. Industri tahu membutuhkan air untuk proses sortasi, perendaman, pengupasan kulit, penggilingan, perebusan dan penyaringan. Pabrik tahu dalam proses pengolahannya menghasilkan limbah, baik limbah padat maupun cair. Limbah padat dihasilkan dari proses penyaringan dan penggumpalan. Sedangkan limbah cair dari proses pencucian, perebusan, pengepresan, dan pencetakkan tahu dihasilkan dalam jumlah yang sangat besar. Limbah cair tersebut mengandung bahan organik tinggi dengan kadar BOD dan COD yakni berkisar antara 7.000-10.000 ppm, serta mempunyai keasaman yang rendah yakni pH 4-5. Dengan kondisi seperti tersebut, air limbah industri tahu merupakan salah satu sumber pencemaran 
lingkungan akan menurunkan daya dukung lingkungan (Moertinah dan Djrawanti, 2003).

Pengurangan kadar zat-zat organik yang ada dalam limbah industri tahu sebelum dibuang ke perairan, dapat dilakukan dengan mengadsorpsi zat-zat tersebut menggunakan adsorben. Salah satu adsorben yang memiliki kemampuan adsorpsi yang besar adalah zeolit alam.Kemampuan adsorpsi zeolit alam akan meningkat apabila zeolit terlebih dahulu diaktifkan. Adsorpsi adalah penumpukan materi pada interface antara dua fasa (Herlambang, 2002).

Zeolit merupakan senyawa alumina silika ( $\mathrm{Si} / \mathrm{Al})$ mempunyai pori dan luas permukaan yang relative besar, sehingga mempunyai sifat adsorpsi yang tinggi.Bentuk kristal zeolit relatif teratur dengan rongga yang saling berhubungan ke segala arah menyebabkan permukaan zeolit menjadi sangat luas sehingga baik untuk digunakan sebagai adsorben (Arnelli dkk., 1999).

Pada penenlitian ini akan dilakukan aktivasi zeolit alam terlebih dahulu dengan menggunakan larutan $\mathrm{HCl} 6 \mathrm{~N}$ dan $\mathrm{NH}_{4} \mathrm{NO}_{3} 2 \mathrm{~N}$. Aktivasi ini bertujuan untuk membersihkan permukaan pori dan menghilangkan senyawa pengotor.

\section{Bahan}

\section{MATERI DAN METODE}

Zeolit alam, $\mathrm{HCl}, \mathrm{NH}_{4} \mathrm{NO}_{3} 2 \mathrm{~N}, \mathrm{~Pb}\left(\mathrm{NO}_{3}\right)_{2}$, $\mathrm{K}_{2} \mathrm{Cr}_{2} \mathrm{O}_{7} \quad 0,025 \mathrm{~N} ; \quad \mathrm{Ag}_{2} \mathrm{SO}_{4}-\mathrm{H}_{2} \mathrm{SO}_{4}$, indikator ferroin, $\mathrm{Fe}\left(\mathrm{NH}_{4}\right)_{2}\left(\mathrm{SO}_{4}\right)_{2} 0,1 \mathrm{~N} ; \mathrm{MnSO}_{4}$, Alkali iodida azida, $\mathrm{Na}_{2} \mathrm{~S}_{2} \mathrm{O}_{3} 0,025 \mathrm{~N} ; \mathrm{NaOH}$, amilum, akuades, batu didih, dan kertas saring.

\section{Peralatan}

Labu Erlenmeyer $250 \mathrm{~mL}$; beakerglass $250 \mathrm{~mL}$; labu ukur10, 20, 25, 100, dan $1000 \mathrm{~mL}$; pipet volume 2, 5, 10, 20, dan $30 \mathrm{~mL}$; buret $10 \mathrm{~mL}$, $25 \mathrm{~mL}$; neraca analitik; grinder; ayakan; corong buchner; pompa vakum; oven pemanas; furnace; desikator; $\mathrm{pH}$ meter; shaker; sentrifuge; pembakar spirtus; botol kaca ukuran $50 \mathrm{~mL}$; dan COD reactor Hach.

\section{Cara Kerja \\ Persiapan Awal Zeolit}

Zeolit alam dihancurkan kemudian diayak pada ukuran 100 mesh.Zeolit kemudian dipanaskan dalam oven pada suhu $120{ }^{\circ} \mathrm{C}$ selama 4 jam.

\section{Aktivasi Zeolit}

Aktivasi zeolit dalam penelitian ini dilakukan dengan cara dealuminasi zeolit alam dengan menggunakan $\mathrm{HCl} 6 \mathrm{~N}$ dan $\mathrm{NH}_{4} \mathrm{NO}_{3} 2 \mathrm{~N}$. Konsentrasi tersebut merupakan konsentrasi maksimum untuk dealuminasi zeolit alam (Ermawati, 2003).

Sebanyak $200 \mathrm{~g}$ zeolit alam direfluk dengan $400 \mathrm{~mL} \mathrm{HCl} 6 \mathrm{~N}$. Campuran selanjutnya disaring dan dicuci dengan akuades hingga filtrat menunjukkan $\mathrm{pH}$ sama dengan $\mathrm{pH}$ aquades. Filtrat kemudian ditetesi dengan $\mathrm{Pb}\left(\mathrm{NO}_{3}\right)_{2}$ hingga tidak terbentuk endapan.

Setelah kering, kemudian zeolit direfluk kembali dengan $\mathrm{NH}_{4} \mathrm{NO}_{3} 2 \mathrm{~N}$ selama 4 jam. Campuran disaring dan dicuci dengan akuades hingga filtrat menunjukkan $\mathrm{pH}$ sama dengan $\mathrm{pH}$ aquades. Filtrat kemudian dianalisis dengan menambahkan $\mathrm{NaOH} 2 \mathrm{M}$ untuk mengendapkan $\mathrm{Al}(\mathrm{OH}) 3$. Residu lalu dikeringkan dalam oven 300 0C selama 4 jam untuk menghilangkan amoniak (Ermawati, 2003).

\section{Penentuan Rasio Massa Optimum}

Masing-masing sebanyak 0,$5 ; 1,0 ; 1,5$; dan 2,0 g zeolit ditambah $10 \mathrm{~mL}$ air limbah. Campuran dishaker selama 150 menit pada suhu $30^{\circ} \mathrm{C}$ kemudian disentrifuge (Arthono, 2001). Dipisahkan antara filtrat dan residu, kemudian filtratnya diukur nilai BOD dan COD-nya.

\section{Penentuan Suhu Optimum}

Sebanyak massa optimum (1,5 g) zeolit ditambah $10 \mathrm{~mL}$ air limbah. Campuran selanjutnya kemudian digojog dalam shaker selama 150 menit masing-masing pada 30,40 dan $50{ }^{\circ} \mathrm{C}$ kemudian disentrifuge (Arthono, 2001).

Filtrat dan residu dipisahkan, kemudian filtratnya diukur nilai BOD dan COD-nya (Srihapsari, 2005).

\section{Analisis BOD dengan Metode Titrasi Winkler}

Sampel dimasukkan ke dalam dua botol kaca, masing-masing $50 \mathrm{~mL}$. Salah satu dari botol tersebut diinkubasi selama lima hari, kemudian diukur oksigen terlarutnya. Botol yang tersisa diukur oksigen terlarutnya pada hari ke nol dengan menambahkan 0,5 $\mathrm{mL} \mathrm{MnSO}_{4}+0,5 \mathrm{~mL}$ reagen alkali iodida azida $+0,5 \mathrm{~mL} \mathrm{H}_{2} \mathrm{SO}_{4}$ pekat. Setelah itu ditambah 3 tetes amilum dan dititrasi dengan 
larutan natrium thiosulfat.Selanjutnya dilakukan perhitungan BOD dan penurunan BOD limbah tahu sebelum dan sesudah perlakuan (Alaerts dan Santika, 1984).

\section{Analisis COD dengan Metode Refluk Tertutup}

Sebanyak $2 \mathrm{~mL}$ sampel diambil, kemudian dimasukkan ke dalam tabung COD. Setelah itu ditambah dengan $40 \mathrm{mg} \mathrm{HgSO}_{4}, 1 \mathrm{~mL} \mathrm{~K}_{2} \mathrm{Cr}_{2} \mathrm{O}_{7}$ $0,025 \mathrm{~N}, 3 \mathrm{~mL}$ reagen yang berisi campuran $\mathrm{Ag}_{2} \mathrm{SO}_{4}$ dan $\mathrm{H}_{2} \mathrm{SO}_{4}$ kemudian mulut tabung COD ditutup rapat, dikocok sampai homogen. Selanjutnya tabung COD beserta isinya dimasukkan ke dalam COD reaktor, tekan tombol on, pengatur suhu $150{ }^{\circ} \mathrm{C}$, putar pengatur waktu sampai angka 120 menit, kemudian dibiarkan sampai bel berbunyi, dan tekan tombol off. Tabung didinginkan, kemudian larutan dimasukkan ke dalam erlenmeyer, ditambah 2 tetes indikator ferroin, dan dititrasi dengan larutan Ferro Ammonium Sulfat 0,0926 N. Selanjutnya dilakukan perhitungan COD dan penurunan COD limbah tahu sebelum dan sesudah perlakuan limbah tahu (Pranoto, 2005).

\section{HASIL DAN PEMBAHASAN}

\section{Pengaruh Massa Zeolit Alam Teraktivasi pada Perlakuan Limbah Cair Tahu Terhadap Penurunan BOD}

Kadar BOD sebelum mengalami perlakuan dengan zeolit alam teraktivasi memiliki nilai yang lebih besar dibandingkan dengan limbah tahu yang mengalami perlakuan dengan zeolit aktif, yaitu sebesar 260,96 mg/L.

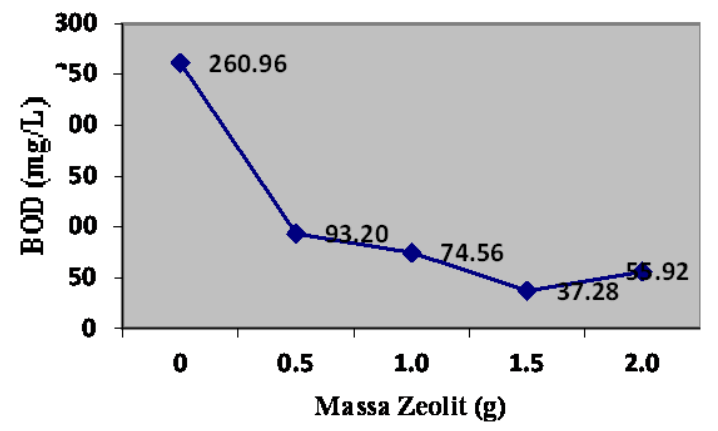

Gambar 1. Massa optimum Zeolit terhadap BOD

Massa optimum diperoleh pada massa zeolit 1,5 g dengan nilai BOD 37,28 mg/L.

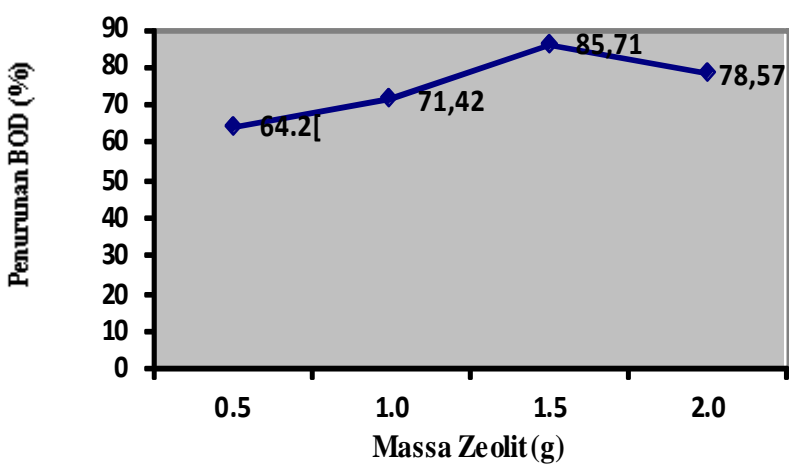

Gambar 2. Massa optimum Zeolit terhadap Penurunan BOD

Pada penelitian ini penurunan BOD mencapai nilai optimum $85,7 \%$.

Pengaruh Suhu Limbah pada Perlakuan Limbah Cair Tahu Terhadap Penurunan BOD

Variasi suhu limbah yang digunakan pada penelitian ini adalah 30,40 , dan $50{ }^{\circ} \mathrm{C}$.

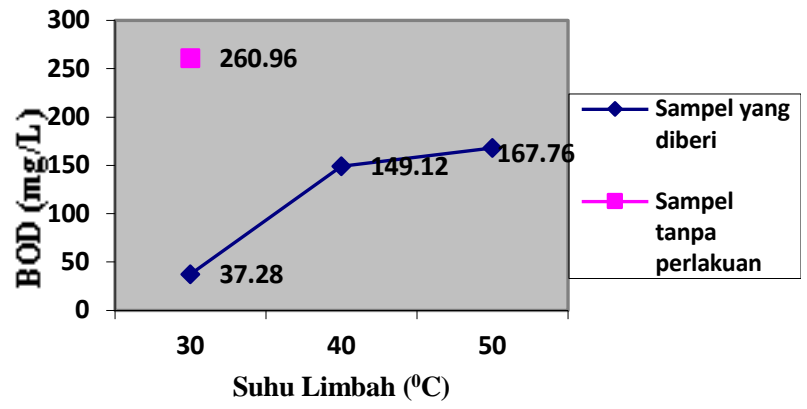

Gambar 3. Pengaruh Suhu terhadap BOD

Dari ketiga variasi suhu yang diujikan, yang mampu menurunkan BOD paling besar yaitu suhu $30{ }^{\circ} \mathrm{C}$. Hal ini berarti bahwa proses adsorpsi yang berlangsung maksimum pada suhu rendah. Peristiwa ini merupakan salah satu ciri fisisorpi. 


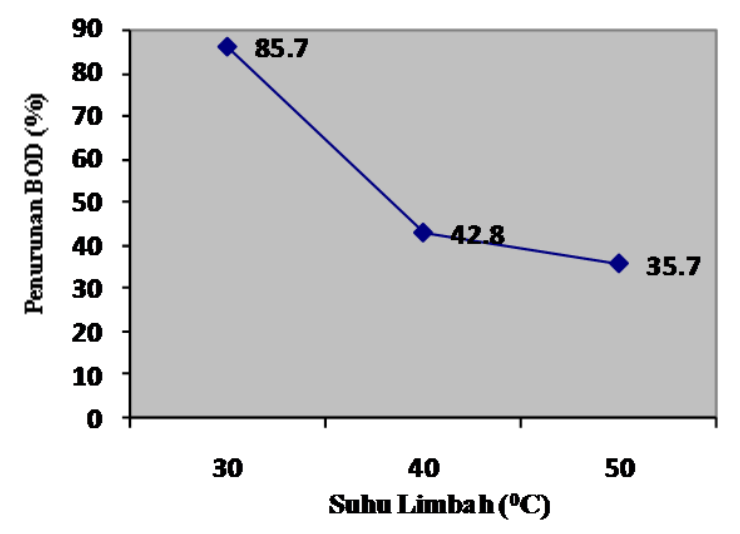

Gambar 4. Pengaruh Suhu terhadap Penurunan BOD

Penurunan yang terjadi pada suhu $30{ }^{\circ} \mathrm{C}$ adalah sebesar $85,7 \%$. Semakin tinggi suhu limbah menunjukkan penurunan BOD semakin kecil. Adsorpsi yang terjadi pada suhu rendah adalah adsorpsi fisik.

Pengaruh Massa Zeolit Alam Teraktivasi pada Perlakuan Limbah Cair Tahu Terhadap Penurunan COD

COD limbah tahu sebelum mengalami perlakuan dengan zeolit alam teraktivasi memiliki nilai sebesar 279,65 mg/L. Nilai COD semakin turun dengan bertambahnya massa zeolit alam teraktivasi dalam limbah.

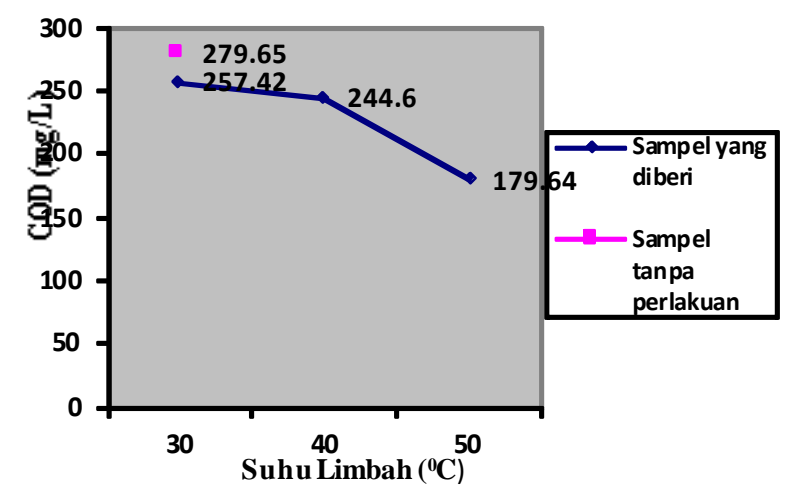

Gambar 5. Massa optimum Zeolit terhadap COD

Nilai COD semakin menurun dan mencapai titik optimum pada penambahan zeolit alam teraktivasi $1,5 \mathrm{~g}$. Selanjutnya pada massa 2,0 g COD kembali naik. Hal ini disebabkan semakin besar perbandingan zeolit alam teraktivasi dalam volume limbah yang sama, maka kemungkinan terjadinya interaksi antara zat-zat organik dalam limbah dengan zeolit alam teraktivasi lebih besar

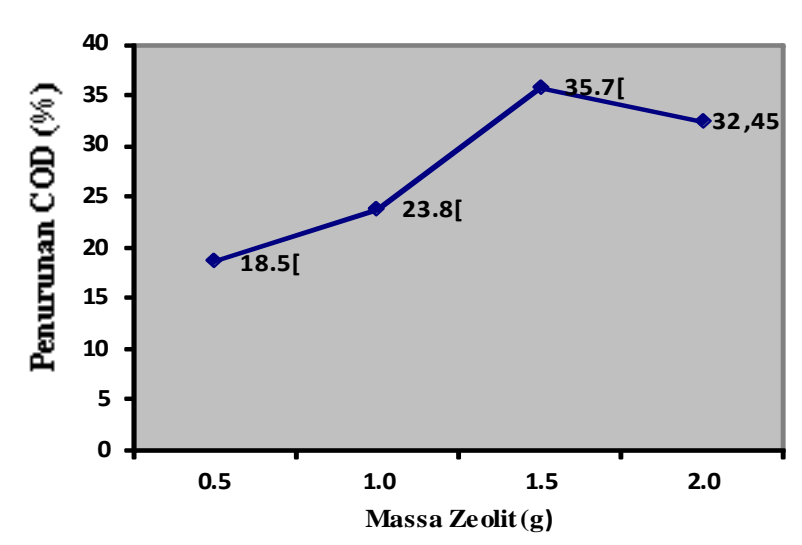

Gambar 6. Massa optimum Zeolit terhadap Penurunan COD

Penurunan COD optimum terajdi pada interaksi $1,5 \mathrm{~g}$ zeolit alam teraktivasi dengan penurunan COD hingga $35,7 \%$.

\section{Pengaruh Suhu Limbah pada Perlakuan Limbah Cair Tahu Terhadap Penurunan COD}

Semakin tinggi suhu pada saat proses penggojogan, sampel memiliki COD yang lebih besar dibandingkan pada suhu yang lebih rendah.

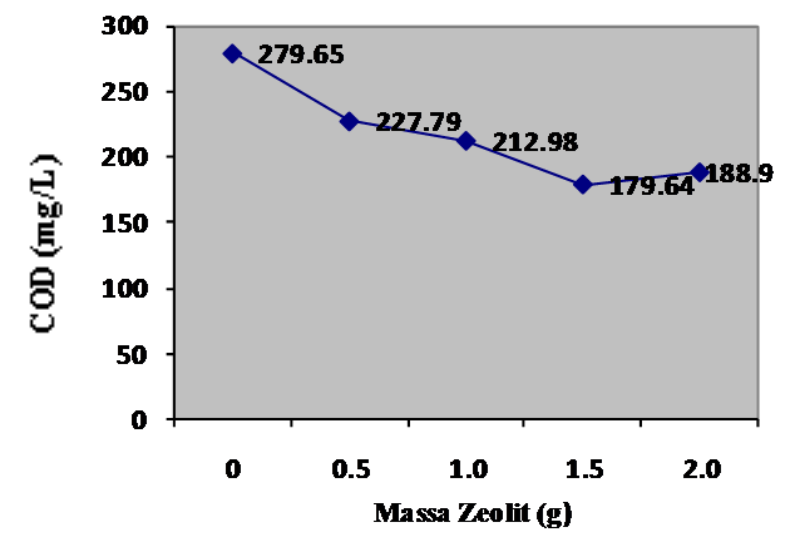

Gambar 7. Pengaruh Suhu terhadap COD

Nilai COD mengalami penurunan lebih besar pada limbah yang paling rendah. Proses adsorpsi pada peristiwa ini dapat berlangsung lebih maksimal pada suhu rendah, yang merupakan ciri fisisorpi. 
(Ni Wayan Trisnadewi, Ketut Gede Dharma Putra dan I Nengah Simpen)

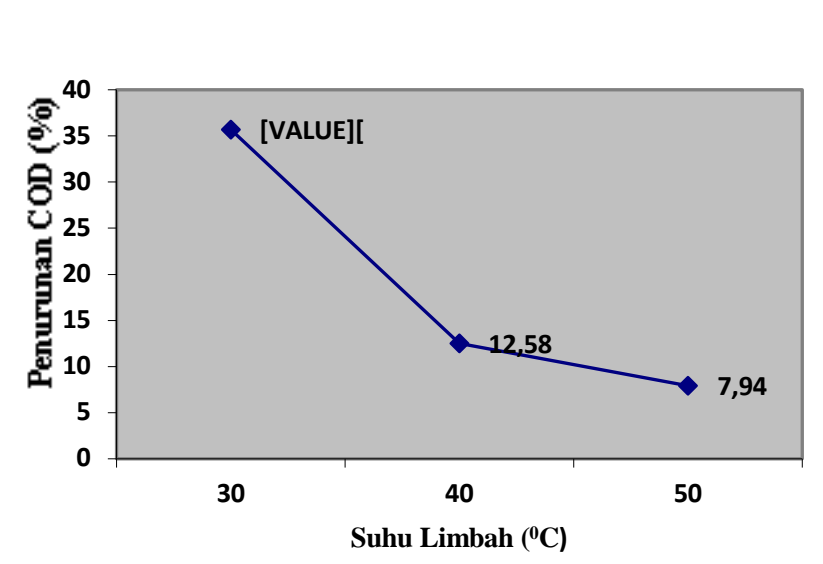

Gambar 8. Pengaruh Suhu terhadap Penurunan COD

Pada suhu $30{ }^{0} \mathrm{C}$ COD limbah tahu mengalami penurunan hingga $35,7 \%$. Angka ini terus menurun pada suhu yang lebih tinggi yaitu 40 dan $50{ }^{\circ} \mathrm{C}$.

\section{SIMPULAN DAN SARAN}

\section{Simpulan}

Berdasarkan hasil penelitian dan pembahasan, maka dapat disimpulkan sebagai berikut :

1. Rasio massa optimum zeolit dalam limbah, pada penurunan BOD dan COD limbah cair industri tahudengan zeolit alam teraktivasi sebagai adsorben adalah $1,5 \mathrm{~g}$.

2. Suhu optimum penurunan BOD dan COD limbah cair industri tahu dengan zeolit alam teraktivasi sebagai adsorben adalah $30{ }^{\circ} \mathrm{C}$.

3. Persentase maksimum penurunan BOD dan COD limbah cair industri tahu dengan zeolit alam teraktivasi sebagai adsorben masingmasing adalah 85,7 dan $35,7 \%$.

\section{Saran}

Dari penelitian yang telah dilakukan, disarankan bahwa perlu dilakukan penelitian mengenai cara aktivasi zeolit yang lain dengan karakterisasi untuk menurunkan BOD dan COD limbah cair industri tahu.

\section{UCAPAN TERIMA KASIH}

Penulis mengucapkan terima kasih kepada seluruh staff UPT. Laboratorium Analitik Universitas Udayana dalam membantu kelancaran penelitian ini.

\section{DAFTAR PUSTAKA}

Arnelli, Hermawati, L., dan Ismaryata, 1999, Kegunaan Zeolit Termodifikasi Sebagai Penyerap Anion, Laporan Penelitian, UNDIP, Semarang

Alaerts dan Santika, S.S., 1984, Metode Penelitian Air, Usaha Nasional, Surabaya

Arthono, T., 2001, Adsorpsi Pati dalam Limbah Cair Tapioka oleh Zeolit Terdealuminasi, Skripsi, UNDIP, Semarang

Amelia, R., 2003, Pengaruh Konsentrasi Molekul Pengarah Terhadap Kristalinitas dan Komposisi Mineral Zeolit Pda Modifikasi Zeolit Alam Wonosari, Skripsi, UNDIP, Semarang

Ermawati, Y., 2003, Pengaruh Konsentrasi $\mathrm{HCl}$ dan $\mathrm{NH}_{4} \mathrm{NO}_{3}$ Terhadap Dealuminasi Zeolit Alam Wonosari, Skripsi, UNDIP, Semarang

Herlambang, A., 2002, Teknologi Pengolahan Limbah Cair Industri, BPPT dan Bapedal, Samarinda

Moertinah, S. dan Djarwanti, 2003, Penelitian Identifikasi Pencemaran Industri Kecil Tahu-Tempe di Kelurahan Debong Tengah Kota Tegal dan Konsep Pengendaliannya, Laporan Penelitian, Badan Penelitian dan Pengembangan Industri, Semarang

Pranoto, M., 2005, Penggunaan Biofilter Enceng Gondok (Eichhornia crassipes mart solm) untuk Menurunkan Kadar COD Limbah Cair dari Pabrik Tahu, Skripsi, UNNES, Semarang

Srihapsari, D., 2005, Penggunaan Zeolit Alam Yang Telah Diaktivasi dengan Larutan $\mathrm{HCl}$ untuk Menjerap Logam-logam Penyebab Kesadahan Air, Skripsi, UNNES, Semarang 